\title{
MULTILINGUA
}

\section{JOURNAL OF CROSS-CULTURAL}

AND INTERLANGUAGE COMMUNICATION

\section{EDITOR}

Ingrid Piller

Department of Linguistics

Macquarie University, Australia

EDITORIAL ASSISTANT

Hanna Irving Torsh

Macquarie University, Australia

EDITORIAL BOARD

Philipp Angermeyer

York University, Canada

Jinhyun Cho

Macquarie University, Australia

Eva Codó

Universitat Autònoma de Barcelona,

Spain

Alexandre Duchêne

Université de Fribourg, Switzerland

Ingrid Gogolin

Hamburg University, Germany

Alexandra Grey

University of Sydney, Australia

Nelson Flores

University of Pennsylvania, USA
Huamei Han

Simon Fraser University, Canada

Adam Jaworski

University of Hong Kong, China

Petteri Laihonen

University of Jyväskylä, Finland

Sabine Little

University of Sheffield, UK

Ikuko Nakane

University of Melbourne, Australia

Joseph Sung-Yul Park

National University of Singapore,

Singapore

Fatma Said

Goldsmiths, University of London, University of York, UK

Laura Smith-Khan

University of Technology Sydney,

Australia

Jie Zhang

Zhongnan University of Economics and Law, PR China

\section{DE GRUYTER \\ MOUTON}


ABSTRACTED/INDEXED IN Baidu Scholar · BLL Bibliographie Linguistischer Literatur · Cabell's Whitelist · CNKI Scholar (China National Knowledge Infrastructure) · CNPIEC: cnpLINKer .

Dimensions · EBSCO (relevant databases) · EBSCO Discovery Service · ERIC (Education Resources Information Center) · ERIH PLUS (European Reference Index for the Humanities and Social Sciences) · Gale/Cengage · Genamics JournalSeek · Germanistik · Google Scholar · IBR (International Bibliography of Reviews of Scholarly Literature in the Humanities and Social Sciences) · IBZ (International Bibliography of Periodical Literature in the Humanities and Social Sciences) - Index Copernicus · International Bibliography of the Social Sciences (ProQuest) $\cdot$ J-Gate $\cdot$ Journal Citation Reports/Social Sciences Edition · JournalGuide · JournalTOCs · KESLI-NDSL (Korean National Discovery for Science Leaders) · Linguistic Bibliography $\cdot$ Linguistics Abstracts Online · Microsoft Academic $\cdot$ MLA International Bibliography $\cdot$ MyScienceWork $\cdot$ Naver Academic $\cdot$ Naviga (Softweco) · Norwegian Register for Scientific Journals, Series and Publishers · OLC Linguistik · Primo Central (ExLibris) · ProQuest (relevant databases) · Publons · QOAM (Quality Open Access Market) - ReadCube - SCImago (SJR) - SCOPUS · Semantic Scholar · Sherpa/RoMEO - Summon (ProQuest) · TDNet · Ulrich's Periodicals Directory/ulrichsweb · WanFang Data - Web of Science: Arts \& Humanities Citation Index; Social Sciences Citation Index · WorldCat (OCLC)

The publisher, together with the authors and editors, has taken great pains to ensure that all information presented in this work reflects the standard of knowledge at the time of publication. Despite careful manuscript preparation and proof correction, errors can nevertheless occur. Authors, editors and publisher disclaim all responsibility for any errors or omissions or liability for the results obtained from use of the information, or parts thereof, contained in this work.

ISSN 0167-8507 · e-ISSN 1613-3684

All information regarding notes for contributors, subscriptions, Open access, back volumes and orders is available online at www.degruyter.com/journals/multilin

RESPONSIBLE EDITOR Ingrid Piller, Department of Linguistics, Macquarie University, NSW 2109, Australia, e-mail: ingrid.piller@mq.edu.au

PUBLISHER Walter de Gruyter GmbH, Berlin/Boston, Genthiner Straße 13, 10785 Berlin, Germany

JOURNAL MANAGER Juliane Herzer, De Gruyter, Genthiner Straße 13, 10785 Berlin, Germany, Tel: +49 (0)30 260 05-380, Fax: +49 (0)30 260 05-250,

e-mail: juliane.herzer@ degruyter.com

RESPONSIBLE FOR ADVERTISEMENTS Kevin Göthling, De Gruyter, Genthiner Straße 13, 10785 Berlin, Germany, Tel.: +49 (0)30 260 05-170, e-mail: anzeigen@ degruyter.com

(C) 2020 Walter de Gruyter GmbH, Berlin/Boston, Germany

TYPESETTING TNQ Technologies, Chennai, India

PRINTING Franz X. Stückle Druck und Verlag e.K., Ettenheim

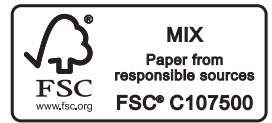




\section{Contents}

Special Issue: Linguistic diversity in a time of crisis: Language challenges of the COVID-19 pandemic

Guest Editors: Jie Zhang and Jia Li

\section{Articles}

Ingrid Piller, Jie Zhang and Jia Li

Linguistic diversity in a time of crisis: Language challenges of the COVID-19

pandemic -503

Jie Zhang and Yuqin Wu

Providing multilingual logistics communication in COVID-19 disaster relief -517

Jia Li, Ping Xie, Bin Ai and Lisheng Li

Multilingual communication experiences of international students during the COVID-19 Pandemic — 529

In Chull Jang and Lee Jin Choi

Staying connected during COVID-19: The social and communicative role of an ethnic online community of Chinese international students in South

Korea - 541

Leticia-Tian Zhang and Sumin Zhao

Diaspora micro-influencers and COVID-19 communication on social media: The case of Chinese-speaking YouTube vloggers — 553

Xi Chen

Fighting COVID-19 in East Asia: The role of classical Chinese poetry - 565

Gegentuul Hongye Bai

Fighting COVID-19 with Mongolian fiddle stories - 577

Yongyan Zheng

Mobilizing foreign language students for multilingual crisis translation in Shanghai -587 
Chun-Mei Chen

Public health messages about COVID-19 prevention in multilingual

Taiwan 597

Hongqiang Zhu

Countering COVID-19-related anti-Chinese racism with translanguaged swearing on social media -607

Yuming Li, Gaoqi Rao, Jie Zhang and Jia Li

Conceptualizing national emergency language competence — 617

Qi Shen

Commentary: Directions in language planning from the COVID-19 pandemic -625 